\title{
THE GENETICS OF EGG-HATCHING IN DROSOPHILA
}

\author{
A. J. BATEMAN \\ Cytogenetics Laboratory, Christie Hospital and Holt Radium Institute, \\ Manchester
}

\section{MATERIALS AND METHODS}

Received 26.vii.6r

For some projected experiments on X-ray induced dominant lethal mutation rates in Drosophila melanogaster it was desirable to use stocks in which the natural proportion of unhatched eggs was very low and constant. A preliminary survey was therefore madc of crosses between a few available inbred lines with the intention of improving the hatching rate by heterosis. It was then found that there was a marked difference in performance of $F_{1}$ parents between the reciprocal crosses between two lines designated $\mathrm{O}$ and $\mathrm{B}$. When $\mathrm{B}$ females werc crossed to $\mathrm{O}$ males the $F_{1}$ parents (symbol $B O$ ) gave I per cent. unhatched eggs whereas the reciprocal $F_{1}(O B)$ gave 35 per cent. unhatched eggs. This reciprocal difference was further investigated, using various combinations of $\mathrm{O}$ and $\mathrm{B}$ chromosomes in $\mathrm{O}$ and $\mathrm{B}$ critoplasm.

The following types of female were used : $\mathrm{B}, \mathrm{O}, \mathrm{OB}, \mathrm{BO}, \mathrm{OB} \times \mathrm{B}$ (backcross of $\mathrm{OB}$ female to a $\mathrm{B}$ male), $\mathrm{B} \times \mathrm{OB}, \mathrm{BO} \times \mathrm{O}$ and $\mathrm{O} \times \mathrm{OB}$. This excludes the $\mathrm{F}_{2}$ 's and half the backcrosses, but is symmetrical. Only three types of male were used : $\mathrm{B}, \mathrm{O}$ and $\mathrm{BO}$, as it was anticipated that female constitution would be much more important than male constitution. It is unfortunate that $\mathrm{OB}$ males were not also used to preserve the symmetry.

All combinations of male and female types were mated in units of 3 females to 3 males in an endeavour to reduce the effect of segregation for hatchability within each type. Parents were mated for 24 hours and then transferred to a tube containing a $3 \times 1$ in. slide coated on one side with a special medium. After 24 hours' laying the parents were shaken out and after a further 24 hours hatched and unhatched eggs were counted. Mating, laying and hatching all occurred at $25^{\circ} \mathrm{C}$. (for details of technique see Bateman, 1956). The total eggs counted for each mating tube and the percentages unhatched are given in full in table $\mathrm{I}$.

Table 2 shows the weighted means for percentage of unhatched eggs, together with row and column totals from which first order effects may be judged. For the interpretation of these data one must consider the genotypes of the various males and females and of the eggs before and after fertilisation. These can be expressed by parameters which are shown in table 3 .

(i) With or without $\mathrm{O}$ cytoplasm, which here refers to anything which is inherited permanently and only through the female line. It refers equally, of course, to the cytoplasm of the egg and of the female laying it.

(ii) The proportion of $\mathrm{O}$ genes in the female and in the unfertilised egg, which will vary from o in inbred line $B$ to $I$ in inbred line $O$.

(iii) The heterozygosity of the female, which will measure her heterosis. This will vary from $o$ in inbred lines to $I$ in $F_{1}$.

(iv) The proportion of $\mathrm{O}$ genes in the fertilised egg, separate values pertaining to each type of male, and

(v) The amount of heterozygosity in the fertilised egg, for which again separate values pertain to each type of male.

In addition to the above there might be (vi) an effect of male genotype per se and (vii) interactions between male and female (or egg) genotypes. 
TABLE I

Detailed results from all matings

\begin{tabular}{|c|c|c|c|c|c|c|}
\hline \multirow[b]{2}{*}{ कq } & \multicolumn{2}{|c|}{ B } & \multicolumn{2}{|c|}{$\mathrm{O}$} & \multicolumn{2}{|c|}{$\mathrm{BO}$} \\
\hline & No. eggs & $\begin{array}{l}\text { Per cent. } \\
\text { unhatched }\end{array}$ & No. eggs & $\begin{array}{l}\text { Per cent. } \\
\text { unhatched }\end{array}$ & No. eggs & $\begin{array}{l}\text { Per cent. } \\
\text { unhatched }\end{array}$ \\
\hline B & $\begin{array}{r}33 \\
72 \\
117 \\
152 \\
15 \\
75 \\
102\end{array}$ & $\begin{array}{l}21 \cdot 2 \\
\text { I } 5.3 \\
\text { I } 5.4 \\
18 \cdot 4 \\
12.0 \\
27.5\end{array}$ & $\begin{array}{r}119 \\
126 \\
66 \\
\\
33 \\
11 \\
90\end{array}$ & $\begin{array}{c}16.8 \\
14.3 \\
15.2 \\
100 \\
100 \\
5.6\end{array}$ & $\begin{array}{r}84 \\
102 \\
83 \\
115 \\
91 \\
161 \\
91 \\
91 \\
92\end{array}$ & $\begin{array}{r}16 \cdot 7 \\
13 \cdot 7 \\
9 \cdot 6 \\
11 \cdot 3 \\
3 \cdot 3 \\
7 \cdot 5 \\
6 \cdot 6 \\
30 \cdot 4\end{array}$ \\
\hline O & $\begin{array}{r}115 \\
147 \\
158 \\
\\
103 \\
53 \\
117\end{array}$ & $\begin{array}{l}48 \cdot 7 \\
56 \cdot 5 \\
31 \cdot 0 \\
\\
51 \cdot 5 \\
45 \cdot 3 \\
71 \cdot 8\end{array}$ & $\begin{array}{r}145 \\
104 \\
80 \\
\\
147 \\
91 \\
146\end{array}$ & $\begin{array}{r}13.8 \\
18.3 \\
27.5 \\
\\
15.6 \\
5.5 \\
41.8\end{array}$ & $\begin{array}{r}77 \\
132 \\
170 \\
110 \\
112 \\
59 \\
94 \\
48\end{array}$ & $\begin{array}{c}9 \cdot 1 \\
79 \cdot 5 \\
78 \cdot 2 \\
50 \cdot 9 \\
92 \cdot 9 \\
57 \cdot 6 \\
72 \cdot 3 \\
85 \cdot 4\end{array}$ \\
\hline $\mathrm{OB}$ & $\begin{array}{l}179 \\
200\end{array}$ & $\begin{array}{l}39 \cdot 7 \\
34 \cdot 5\end{array}$ & $\begin{array}{r}40 \\
153 \\
99\end{array}$ & $\begin{array}{l}2.5 \\
0.7 \\
1.0\end{array}$ & $\begin{array}{r}210 \\
83 \\
164 \\
197\end{array}$ & $\begin{array}{l}42 \cdot 4 \\
48 \cdot 2 \\
15 \cdot 2 \\
34 \cdot 0\end{array}$ \\
\hline $\mathrm{BO}$ & $\begin{array}{r}97 \\
167 \\
174\end{array}$ & $\begin{array}{l}6 \cdot 2 \\
9 \cdot 0 \\
3 \cdot 4\end{array}$ & $\begin{array}{l}198 \\
181 \\
176\end{array}$ & $\begin{array}{l}2 \cdot 0 \\
0.0 \\
0.6\end{array}$ & $\begin{array}{l}130 \\
184 \\
223 \\
189\end{array}$ & $\begin{array}{l}0 \cdot 8 \\
I \cdot 1 \\
0 \cdot 4 \\
3 \cdot 2\end{array}$ \\
\hline $\mathrm{OB} \times \mathrm{B}$ & $\begin{array}{l}141 \\
151 \\
174\end{array}$ & $\begin{array}{l}63 \cdot 8 \\
31 \cdot 8 \\
39 \cdot 7\end{array}$ & $\begin{array}{r}73 \\
110 \\
145\end{array}$ & $\begin{array}{r}2 \cdot 7 \\
4 \cdot 5 \\
30 \cdot 3\end{array}$ & $\begin{array}{l}180 \\
177 \\
108 \\
127\end{array}$ & $\begin{array}{l}56 \cdot 7 \\
50 \cdot 8 \\
67 \cdot 6 \\
55 \cdot 9\end{array}$ \\
\hline $\mathrm{B} \times \mathrm{OB}$ & $\begin{array}{r}100 \\
121 \\
66\end{array}$ & $\begin{array}{r}15.0 \\
7.4 \\
22.7\end{array}$ & $\begin{array}{r}73 \\
132 \\
143\end{array}$ & $\begin{array}{r}15 \cdot 1 \\
4.5 \\
4 \cdot 9\end{array}$ & $\begin{array}{l}174 \\
167 \\
146 \\
109\end{array}$ & $\begin{array}{l}3 \cdot 4 \\
5 \cdot 4 \\
4 \cdot 1 \\
8 \cdot 3\end{array}$ \\
\hline $\mathrm{BO} \times \mathrm{O}$ & $\begin{array}{r}225 \\
\text { I } 33 \\
42\end{array}$ & $\begin{array}{l}18 \cdot 7 \\
32 \cdot 7 \\
23.8\end{array}$ & $\begin{array}{r}153 \\
13^{8} \\
3^{1}\end{array}$ & $\begin{array}{r}10.5 \\
15.9 \\
0.0\end{array}$ & $\begin{array}{l}152 \\
170 \\
157 \\
148\end{array}$ & $\begin{array}{r}3.9 \\
15.9 \\
0.6 \\
4.1\end{array}$ \\
\hline $\mathrm{O} \times \mathrm{BO}$ & $\begin{array}{r}8 \\
61 \\
27\end{array}$ & $\begin{array}{c}\text { I00 } \\
32 \cdot 8 \\
37 \cdot 0\end{array}$ & $\begin{array}{l}127 \\
122 \\
111\end{array}$ & $\begin{array}{r}0.8 \\
22 \cdot 1 \\
9 \cdot 0\end{array}$ & $\begin{array}{l}144 \\
138 \\
127 \\
106\end{array}$ & $\begin{array}{l}69 \cdot 4 \\
68 \cdot 8 \\
61 \cdot 4 \\
55 \cdot 7\end{array}$ \\
\hline
\end{tabular}


TABLE 2

Percentages of unhatched eggs in all kinds of matings and their group totals

\begin{tabular}{|c|c|c|c|c|c|c|c|c|c|}
\hline \multirow{3}{*}{ $q$} & \multicolumn{2}{|c|}{ B ठేర } & \multicolumn{2}{|c|}{ BO 00} & \multicolumn{2}{|c|}{ O ठేర } & \multicolumn{2}{|c|}{ All $0^{\circ} \sigma^{\circ}$} & \multirow{3}{*}{$\begin{array}{c}\text { Grand } \\
\text { total }\end{array}$} \\
\hline & \multicolumn{2}{|c|}{ Cytoplasm } & \multicolumn{2}{|c|}{ Cytoplasm } & \multicolumn{2}{|c|}{ Cytoplasm } & \multicolumn{2}{|c|}{ Cytoplasm } & \\
\hline & $\mathrm{O}$ & 13 & 0 & B & $\mathrm{O}$ & B & $\mathrm{O}$ & B & \\
\hline$F_{1} . \quad$. & $36 \cdot 9$ & $6 \cdot 2$ & $33 \cdot 8$ & I. 4 & $1 \cdot 0$ & 0.9 & $71 \cdot 7$ & $8 \cdot 5$ & $80 \cdot 2$ \\
\hline $\begin{array}{l}\text { Backcross } \\
\text { to } \mathrm{B}\end{array}$ & 44.4 & 13.6 & $5^{6} \cdot 8$ & $5 \cdot 0$ & 15.5 & $6 \cdot 9$ & 116.7 & 25.5 & $142 \cdot 2$ \\
\hline $\begin{array}{l}\text { Backcross } \\
\text { to } O\end{array}$ & 39.5 & 23.4 & $64 \cdot 5$ & 6.4 & 10.6 & II 9 & $114 \cdot 6$ & $41 \cdot 7$ & I $56 \cdot 3$ \\
\hline Pure line & $50 \cdot 4$ & $18 \cdot 3$ & $68 \cdot 3$ & 10.7 & $2 \mathrm{I} \cdot \mathrm{O}$ & $21 \cdot 8$ & 139.7 & $5^{0 \cdot 8}$ & 190.5 \\
\hline All $\$$ 우 & $171 \cdot 2$ & $61 \cdot 5$ & 223.4 & 23.5 & $4^{8 \cdot I}$ & $4^{I} \cdot 5$ & $44^{2} \cdot 7$ & $126 \cdot 5$ & $569 \cdot 2$ \\
\hline o total. & & & & & & & & & \\
\hline
\end{tabular}

TABLE 3

Genotypes of females and of eggs in the various matings

\begin{tabular}{|c|c|c|c|c|c|c|c|c|c|}
\hline \multicolumn{2}{|r|}{ Type of female } & B & $\mathrm{O}$ & $\mathrm{BO}$ & OB & $\begin{array}{l}\mathrm{B} \times \\
\mathrm{OB}\end{array}$ & $\underset{\mathbf{B}}{\mathrm{OB} \times}$ & $\underset{\mathrm{O}}{\mathrm{BO} \times}$ & $\begin{array}{l}\mathrm{O} \times \\
\mathrm{BO}\end{array}$ \\
\hline \multicolumn{2}{|c|}{ Cytoplasm of female and egg } & B & 0 & B & $\mathrm{O}$ & B & $\mathrm{O}$ & B & $\mathrm{O}$ \\
\hline \multicolumn{2}{|c|}{$\begin{array}{l}\text { Proportion of } \mathrm{O} \text { genes in } \\
\text { female and unfertilised egg }\end{array}$} & o & I & $\frac{1}{2}$ & $\frac{1}{2}$ & 4 & 1 & $\frac{3}{4}$ & $\frac{3}{4}$ \\
\hline \multicolumn{2}{|c|}{ Heterozygosity of female } & o & o & I & I & $\frac{1}{2}$ & $\frac{1}{2}$ & $\frac{1}{2}$ & $\frac{1}{2}$ \\
\hline 3 & Fertilised egg & & & & & & & & \\
\hline B3 & $\begin{array}{l}\text { Heterozygosity } \\
\text { Proportion of O genes }\end{array}$ & $\stackrel{0}{\circ}$ & $\frac{1}{1}$ & $\frac{1}{2}$ & $\frac{1}{2}$ & $\begin{array}{l}\frac{1}{4} \\
\frac{1}{8}\end{array}$ & $\frac{1}{1}$ & $\begin{array}{l}3 \\
\frac{3}{8} \\
\frac{1}{8}\end{array}$ & $\frac{3}{4}$ \\
\hline $\mathrm{O}$ & $\begin{array}{l}\text { Heterozygosity } \\
\text { Proportion of O genes }\end{array}$ & $\frac{1}{2}$ & o & $\frac{1}{\frac{1}{3}}$ & $\frac{1}{\frac{1}{3}}$ & $\begin{array}{l}3 \\
\frac{3}{5} \\
8\end{array}$ & $\begin{array}{l}3 \\
\frac{3}{8} \\
\frac{1}{8}\end{array}$ & $\frac{1}{\frac{1}{8}}$ & $\frac{1}{\frac{1}{8}}$ \\
\hline BO & $\begin{array}{l}\text { Heterozygosity } \\
\text { Proportion of } \mathrm{O} \text { genes }\end{array}$ & $\frac{1}{1}$ & $\frac{1}{3}$ & $\frac{1}{2}$ & $\frac{1}{3}$ & $\frac{\frac{1}{3}}{\frac{3}{8}}$ & $\frac{1}{3}$ & $\frac{\frac{1}{5}}{\frac{5}{8}}$ & $\frac{1}{\frac{1}{3}}$ \\
\hline
\end{tabular}

\section{RESULTS}

The statistical significance of the effects discussed below may be judged from a general analysis of variance carried out on the data in table 2. As will be seen from table 4, all the first order effects are highly significant as is also the interaction of cytoplasm and type 
of male. Such an analysis is unable to show the nature of these interactions, which will be discussed below. The mean square for heterozygosity of the female should be greater than the value shown because one of the three degrees of freedom cited is in fact due to the comparison between the backcrosses to $\mathrm{B}$ and $\mathrm{O}$, which have the same heterozygosity.

It will be seen that the third order interaction has a higher mean square (non-significant, $\mathrm{P}<0 \cdot 2$ ) than the second order interactions involving heterozygosity. For that reason these second order interactions have been pooled to make the denominator of the Variance Ratios. If the third order interaction had been used as error the

TABLE 4

Analysis of variance on data of table 2

\begin{tabular}{|c|c|c|c|c|}
\hline & $\begin{array}{l}\text { Degrees of } \\
\text { freedom }\end{array}$ & $\begin{array}{c}\text { Mean } \\
\text { square }\end{array}$ & $\begin{array}{c}\text { Variance } \\
\text { ratio }\end{array}$ & P \\
\hline $\begin{array}{l}\text { Cytoplasm of female }(\mathbf{C}) \\
\text { Heterozygosity of female }(\mathbf{H}) \\
\text { Male }(\mathbf{M}): \\
\mathbf{C} \times \mathbf{M} \\
\mathbf{C} \times \mathbf{H}\end{array}$ & $\begin{array}{l}1 \\
3 \\
2 \\
2 \\
3 \\
6 \\
9 \\
6\end{array}$ & $\begin{array}{r}4165 \cdot 93 \\
354 \cdot 20 \\
946 \cdot 30 \\
1169 \cdot 39 \\
29 \cdot 65 \\
13 \cdot 15 \\
18 \cdot 65 \\
41 \cdot 34 \\
\end{array}$ & $\begin{array}{r}223 \\
19 \\
51 \\
63 \\
\cdots \\
\cdots \\
1 \cdot 00 \\
2 \cdot 2 \\
\end{array}$ & $\begin{aligned}<0.001 \\
<0.001 \\
<0.001 \\
<0.001 \\
\quad \ldots \\
\cdots \\
\quad \ldots \\
<0.2 \\
\end{aligned}$ \\
\hline Total & 23 & & & \\
\hline
\end{tabular}

significances would have been substantially the same as those shown. The first order effects can be recognised in the column and row totals of table 2.

(i) The cytoplasm of the fermale and the egg

With the exception of matings with $\mathrm{O}$ males, eggs with $\mathrm{O}$ cytoplasm always have a higher percentage of unhatched eggs than eggs with $\mathrm{B}$ cytoplasm in the corresponding mating. This even holds when the comparison is between the inbred lines $\mathrm{O}$ and $\mathrm{B}$.

\section{(ii) The heterozygosity of the female}

It will also be seen from table 2 that the inbred females have the highest unhatched rate, the $F_{1}$ have the lowest and the backcrosses (with a heterozygosity of $\frac{1}{2}$ ) are half-way between. As will be seen in fig. I this heterotic effect is the same in both cytoplasms. Heterosis might be operating in several ways, as for example improving the innate viability of the egg, or increasing the efficiency of the mechanism for insemination of each egg before it is laid.

\section{(iii) The genotype of the male}

While $\mathrm{B}$ and $\mathrm{BO}$ males give almost identical mean effects (there is thus no heterotic effect in the male), $\mathrm{O}$ males give much better 
hatching rate than the other two. This is opposite to the effect of $\mathrm{O}$ cytoplasm in the females. As will be shown below, there are strong interactions between female and male genotypes so that this first order effect must not be taken at its face value.

The following factors had no apparent effect: proportion of chromosomal $\mathrm{O}$ genes in the female and unfertilised egg (this is not surprising since the difference between $\mathrm{O}$ and $\mathrm{B}$ was wholly attributable to the cytoplasm); proportion of $\mathrm{O}$ genes in the fertilised egg; and heterozygosity of the fertilised egg. Thus the genetic constitution of the egg appears to be immaterial to the hatching rate. It is not

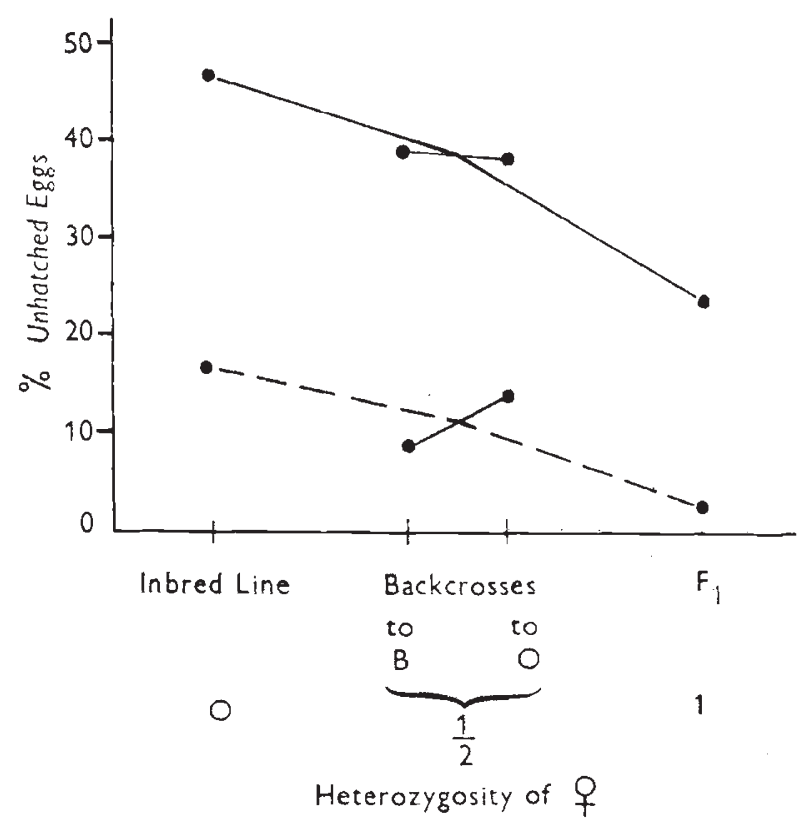

Fic. 1.-The effects of heterozygosity of the $q$ and of cgg cytoplasm on hatchability.

$$
\text { O cytoplasm; - - - B cytoplasm. }
$$

claimed that this is a general law, for in this material since the parent lines were inbred they should be free of egg lethals. One must also conclude, however, that neither did recombination between $O$ and $B$ genes produce egg lethals.

One must now consider interactions betwcen male and female genotypes. For this purpose the effects of the combinations of the 3 main variables are shown graphically in fig. 2. It then becomes apparcnt that the cytoplasmic effect in the egg is dependent on the male being used. The poor hatching of eggs with $\mathrm{O}$ cytoplasm is not shown with $\mathrm{O}$ males. This may be expressed by saying that $\mathrm{O}$ cytoplasm is incompatible with $\mathrm{B}$ and $\mathrm{BO}$ sperm, but $\mathrm{B}$ cytoplasm is equally compatible with $\mathrm{O}, \mathrm{B}$ and $\mathrm{BO}$ sperm. It is now scen that it is this incompatibility which is entirely responsible for the first order effect of both cytoplasm and sperm. 
The reader must not take this interaction between egg cytoplasm and sperm literally, that is, as operating on the gametic level. There could be an inability of $\mathrm{B}$ and $\mathrm{BO}$ sperm to fertilise an egg with $\mathrm{O}$ cytoplasm. On another plane entirely, there could be some kind of inhibition of $\mathrm{B}$ and $\mathrm{BO}$ sperm in the genital tract of females with $\mathrm{O}$ cytoplasm. The extreme case: failure of $\mathrm{B}$ or $\mathrm{BO}$ males to inseminate females with $\mathrm{O}$ cytoplasm can be disregarded, even though no observations were made to determine the rate of insemination.

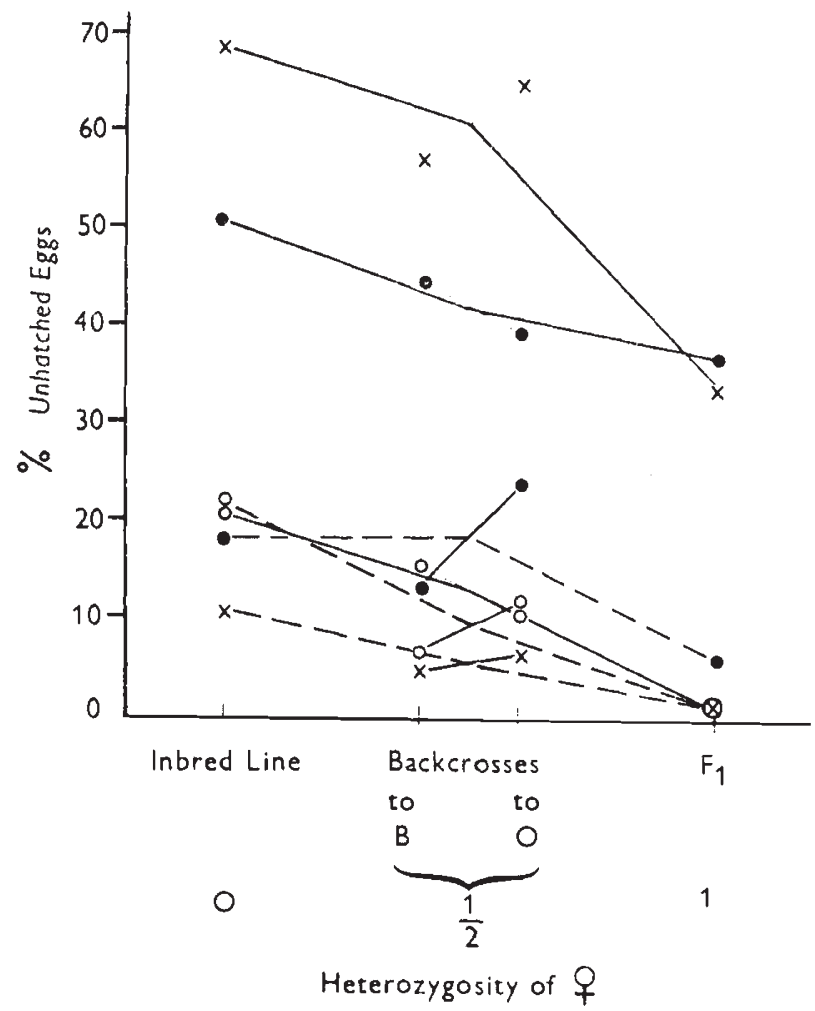

FIG. 2.- The effect of the $\sigma^{t}$ on egg hatchability.

O cytoplasm ; - - - - B cytoplasm

- B sperm ; O O sperm ; $\times$ BO sperm.

In the first place inhibition of mating would have to be very strong indeed to be detectable in matings of 3 flies of each sex for 2 days. In the second place its occurrence would reduce egg laying and the hatching rate showed no correlation with the number of eggs laid.

Though BO and B sperm resemble each other much more closely than either resembles $\mathrm{O}$ sperm, there is still a consistent difference between them. BO sperm gives better hatching in B cytoplasm but worse hatching in $\mathrm{O}$ cytoplasm, differences which cancel out in the combined data. It is as though the heterosis of $\mathrm{BO}$ males produced improved hatching with compatible eggs, but increased incompatibility with incompatible eggs. This is well shown in fig. 2. 
The effect of heterozygosity of the female on hatchability can be seen in fig. 2 over all six combinations of cytoplasm and spcrm. Yet even here there is a suggestion of a third order intcraction in that $\mathrm{BO}$ sperm in $\mathrm{O}$ cytoplasm shows a much stccper curve than any other combination. This may be pushing the analysis too far, however.

\section{FOOTNOTE}

Two years later these same inbred lines were found to have changed their character so that ncither of the reciprocal crosses gave the low proportion of unhatched cggs originally found (one per ccnt.) and I was unable to improve on 5 per cent. Since then I have been unable to find any cross which consistently gave such low proportions of unhatched eggs.

\section{SUMMARY}

In two inbred lincs $B$ and $O$ of Drosophila melanogaster and their various hybrids the following genetic factors werc found to increase the proportion of unhatched cggs, arranged in order of decreasing importance.

I. Incompatibility between eggs with $O$ cytoplasm and sperm of type $\mathrm{B}$ or $\mathrm{BO}$ (the $\mathrm{F}_{1}$ hybrid with $\mathrm{B}$ as the female parent).

2. Homozygosity of the female laying the eggs.

3. Though B and BO sperm showed an overall similarity, B sperm gave more unhatched eggs with $\mathrm{B}$ cytoplasm but $\mathrm{BO}$ sperm gave more unhatched eggs with $\mathrm{O}$ cytoplasm.

The following variables had no detectable effect on egg hatching: egg).

I. Ratio of $\mathrm{O}$ genes to $\mathrm{B}$ genes in the female (and in the unfertilised

2. Ratio of $O$ genes to $B$ genes in the fertilised egg.

3. Heterozygosity of the fertilised egg.

\section{REFERENCE}

eateman, A. J. I956. Mutagenic sensitivity of maturing Drosophila sperm. I. Dominant lethals. 7. Gienetics, 54, 400-4ro. 